\title{
11
}

\section{Hybrid Peacebuilding in Hybrid Communities: A Case Study of East Timor}

\author{
James Scambary and Todd Wassel
}

\section{Introduction}

East Timor achieved independence in 1999 after 24 years of brutal Indonesian military occupation and more than 400 years of Portuguese colonial rule. With the aid of an international peacekeeping force, a United Nations (UN) mission installed an interim administration that set about preparing East Timor for self-governance. However, while its new-found freedom was much celebrated, persistent tensions, rather than unity and peace, came to characterise East Timor's society in the post-independence period. These tensions reached a peak in what is now popularly referred to as the 'Crisis'. From April to June 2006, a rapid series of events resulted in the unravelling of the six-year UN statebuilding project. Nationallevel political tensions and divisions within the security services served as a catalyst for a wider communal conflict on a national scale, which was to last for nearly two years.

In response, a comprehensive, national-level donor and government effort was rolled out to address the perceived causes of this conflict, and get internally displaced people back into their communities. These largely generic, top-down responses included an intensive community mediation campaign and a raft of programs to improve educational and employment 
opportunities. Nonetheless, sporadic communal conflict persisted and, by early 2009, began to increase in both urban and rural areas. Clearly, the sources of violence were more complex and deeply rooted than thought. Longer-term approaches were needed with more local ownership, which would in turn require more hybrid strategies to engage with traditional social structures. As Leonardsson and Rudd, ${ }^{1}$ and others in this publication contend, there is, however, considerable conceptual ambiguity around the concepts of both hybridity and local ownership, with the term 'local', for example, being employed to denote an entire country. This ambiguity is reflected in both theory and practice on peacebuilding in East Timor, where the understanding and use of hybridity has only slowly evolved with a latent appreciation of the highly localised scale and complex nature of conflict.

Hybridity is not new to the East Timor context. A range of government and international non-government organisation (INGO) and donordriven initiatives have engaged some aspect of hybridity in order to secure local ownership since the early independence era. ${ }^{2}$ In addition, the role of traditional authorities in community mediation and security is enshrined by Law No. 3/2009, which sets out the responsibilities of suku (village) councils. ${ }^{3}$ Since 2006, however, hybridity has become a standard component of the mix of approaches to development and peacebuilding by government and international development agencies. Much of this is, though, as described by Millar, top-down and internationally created and administered hybridity. ${ }^{4}$ How hybridity is used by external actors rests on an often idealised, or misconstrued understanding of what constitutes traditional, and what is local. As de Coning notes, the ability of external agents to gain knowledge of the complex and nonlinear social systems often involved in the peacebuilding context is inherently limited. ${ }^{5}$ In East Timor, attempts at hybrid peacebuilding by both international and government agencies have frequently failed to reflect the heterogeneous and dynamic nature of East Timor's society, and the changes it has undergone during the past three decades. These attempts have also, until quite recently, failed to understand the very localised scale and endemic nature of conflict in East Timor. As a consequence, outcomes have been often temporary at best.

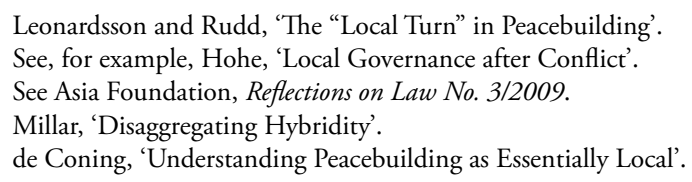


This chapter adopts a case-study approach, drawing on the practical field experiences of both authors over the past decade, to trace the evolution of peacebuilding approaches in East Timor from 2006. It will analyse how both the state and international actors have used hybridity in tandem with changing and more complex understandings of both the nature of conflict and of communities. We argue that to be successful and sustainable in the long term, peacebuilding approaches need a much deeper understanding of societal dynamics, but also need to adopt a more flexible, nuanced and contemporary view of what constitutes 'traditional' and 'local', and recognise that there is more than one variety of hybridity.

This chapter is divided into four sections. The first section addresses the changing nature and understandings of conflict in East Timor, and early attempts at peacebuilding. The next section questions some of the underlying assumptions of these attempts by describing the impact of the Indonesian occupation on traditional social structures and some of the fundamental changes East Timor's society has undergone since independence. We then proceed to analyse the implications of these changes for current peacebuilding approaches. We conclude with a discussion of how more recent and more innovative peacebuilding and policing initiatives, both local and international, have acknowledged some of these complexities and attempted to engage with them.

\section{The post-independence period}

East Timor voted for independence from Indonesia in a UN-sponsored referendum on 30 August 1999. By this time, the violence of the Indonesian-occupation era and the struggle for independence had claimed the lives of approximately 205,000 people. $^{6}$ The violence did not end there. Almost immediately after the vote, Indonesian troops and their proxy militias began a nationwide campaign of murder, violence and systematic destruction of property leading to around 1,200-1,500 deaths and the loss of as much as 85 per cent of East Timor's infrastructure. ${ }^{7}$

Following the restoration of order, the UN Security Council mandated the establishment of the United Nations Transitional Administration of East Timor (UNTAET) to manage East Timor's transition to independence. UNTAET's responsibilities were comprehensive, ranging

6 CAVR, Chega!, 2.

7 Robinson, East Timor 1999, 4. 
from humanitarian assistance through to building the foundations of a new democratic state, including setting up administrative and judicial institutions and the various functions of government.

Despite the euphoria of independence, tensions soon began to surface. One major source of instability arose from the demobilisation process for the former resistance force, Forças Armadas de Libertação Nacional de Timor-Leste (Armed Forces for the National Liberation of East Timor; FALINTIL), and the subsequent recruitment process for the national army, the FALINTIL-Forças de Defesa de Timor-Leste (F-FDTL) and the national police, the Polícia Nacional Timor-Leste (PNTL). Many resistance veterans missed out on jobs in what they regarded as a flawed and secretive process. Angered by their exclusion, and by the fact that 300 former East Timorese members of the Indonesian police force had been recruited into the PNTL, they began to mobilise and engage in often violent demonstrations and attacks on police posts. ${ }^{8}$

Another source of instability, with no apparent relation to any of these issues, was outbursts of communal conflict involving martial arts groups-there are between 15 and 20 of these groups in East Timor. While there are few reliable statistics kept on this period, data from the Ministry of Interior indicate that, between 2002 and 2004, registered cases increased from seven to 37, spreading from four districts in 2002 to 11 of 13 districts in $2004 .{ }^{9}$ The figures also give no indication of the seriousness of the clashes. A riot in March 2001, for example, ostensibly between rival martial arts groups, almost entirely destroyed two villages in Viqueque District in the east of the country. ${ }^{10}$

While generally glossed as martial arts group violence, there are close symmetries between membership of these groups and of descent groups, village boundaries and political-party allegiances. Therefore, martial arts group violence is more often than not a manifestation of deeper communal tensions driven by a range of factors, particularly land disputes, but often of a longstanding historical nature. ${ }^{11}$ Despite the alarming frequency and scale of this subnational conflict, however, any mention of such conflict was largely confined to a few press articles, or buried in donor reports. ${ }^{12}$

8 Shoesmith, 'Timor-Leste', 250.

9 Ostergaard, East Timor Youth Social Analysis Mapping and Youth Institutional Assessment, 23.

10 United Nations Integrated Mission in Timor-Leste, Media Monitoring, Dili, 17 March 2001.

11 Scambary, 'Anatomy of a Conflict'.

12 See, for example, Brown et al., Conflict Assessment: East Timor. 
Peacebuilding approaches in East Timor have until recently been largely reactive, and shaped by changing understandings-or misunderstandings - of the nature of conflict. Conflict was largely understood in the immediate post-independence period in terms of the war of resistance against Indonesian occupation-as something that happened in the past. Beyond the Comissão de Acolhimento, Verdade e Reconciliação de Timor-Leste (Commission for Reception, Truth and Reconciliation in East Timor; CAVR), ${ }^{13}$ which focused on investigating crimes committed from 1974 to 1999 and resolving resultant communal tensions, there were few, if any, government or donor programs or institutions tasked with conflict resolution or mediation, or even major programs specifically addressing youth needs. This all changed after 2006.

On 28 April 2006, a protest by a group of sacked soldiers-known as the 'Petitioners' for their list of demands presented to the governmentdescended into a riot leading to a series of confrontations between the police and army. These confrontations sparked a wider communal conflict which initially assumed the appearance of a regional east versus west divide. ${ }^{14}$ Most accounts of this period have focused on events from April to June $2006,{ }^{15}$ yet the conflict lasted for another 18 months. Once the politically driven east-west nature of the conflict ended in October 2006, the violence took on a very different, and seemingly random dynamic. Conflict continued in the capital, Dili, but erupted in a number of rural areas, particularly in regions that had suffered from endemic violence since independence, and in many cases, long before. There was no discernible overarching political or ethnic narrative for this violence; it now had a distinctly local nature, pitting family against family and village against village, driven by a host of factors including disputed land claims, payback killings and other historical grievances. This type of sporadic, low-level, highly localised conflict has continued to characterise postCrisis violence.

13 The commission was set up under UNTAET Regulation No. 2001/10 (www.un.org/en/peace keeping/missions/past/etimor/untaetR/Reg10e.pdf). CAVR provides an early example of an interesting mix of hybridity. It was run by an all-Timorese commission, with assistance from international staff, but also dealt with customary village-based systems, supporting over 1,400 community reconciliation processes (Braithwaite, 'Evaluating the Timor-Leste Peace Operation', 292).

14 The west in East Timor is considered to be the 10 districts to the west of Dili and the east is the three districts to the east of Dili. See Kammen, 'Subordinating Timor', for a detailed discussion of this cleavage.

15 See, for example, Kingsbury, 'East Timor's Political Crisis'; Sahin, 'Building the State in TimorLeste'. 
Nonetheless, informed by the dubious twin assumptions of this fourmonth time line and that the violence was due to ethnic tensions and youth alienation-a product of rural-urban drift-the government and international donors rolled out a range of national-level vocational training and employment schemes. These initiatives were based on a rather optimistic faith in the redemptive influence of work and education on 'delinquent' youth. At the same time, the United Nations Development Programme and the International Organization for Migration supported government efforts to return internally displaced people to their communities through a process of community mediation and compensation to victims, in order to rebuild community trust and cohesion. ${ }^{16}$

Despite all these efforts, conflict persisted and began to recur with increasing frequency and scale. In the latter half of 2011, a series of highly publicised outbreaks resulted in about six deaths and over 100 houses being burned down, leading to the rather futile banning by the government of martial arts group training, on 22 December 2011. ${ }^{17}$ Alarmed by this upsurge in violence, the government embarked on an intensive community reconciliation program, coordinated by the Ministry of Social Solidarity, which sent mediation teams out to conflict hotspots in Dili and rural areas. A number of INGO programs were also implemented in urban areas of Dili from 2006 to 2010 to engage with the different antagonists such as martials arts groups and violence-afflicted communities.

While some used prescriptive methods simply pulled off the rack from a completely different international context such as Bosnia, many used what could be broadly described as a hybrid approach. They enlisted village chiefs to mobilise communities to attend meetings and to represent their communities in mediation sessions. Traditional rituals such as tara bandu were used to encourage communities to foreswear violence and commit to peace. ${ }^{18}$ These different programs met with mixed success at best. Quite frequently, conflict broke out only a week or two after a supposedly binding tara bandu ceremony took place. In some cases, no community members at all showed up to mediation sessions.

16 RDTL, 'Simu Malu and Fila Fali'.

17 East Timor Subscriber News, 13 January 2012.

18 Tara bandu ceremonies are traditionally employed in natural resource preservation, whereby communities swear under a sacred oath—often accompanied by animal sacrifice-not to eat particular foods or cut down particular plants or trees. 


\section{Hybrid communities}

As Mac Ginty and Richmond claim, some policy approaches to hybridity can be described as 'a shallow latching onto an apparently "trendy" concept ${ }^{19}$ As they argue, artificially created hybrids, manufactured as part of a top-down peacebuilding intervention, can lead to sham processes..$^{20}$ Hybrid approaches to peacebuilding-as stated-are not new in East Timor, although their implementation has been somewhat ad hoc. According to McWilliam et al., tara bandu ceremonies have been employed by international agencies such as the World Bank since 2003. ${ }^{21}$ But while government and INGO willingness to engage with traditional forms of authority is encouraging, these approaches are too often marred by inadequate understandings of the heterogeneous and fluid nature of many communities and local conflicts, and so are rarely more than temporarily effective. Part of the reason for this is that they are often premised on an idealised notion of 'tradition', a common set of assumptions about the legitimacy of traditional authority, and the demographic and territorial integrity and cohesiveness of Timorese society.

As Boege argues, tradition, or 'custom', is in a constant flux. It changes over time and adapts to new circumstances, particularly when exposed to external modernising influences. ${ }^{22}$ East Timor has undergone major demographic changes since independence, with significant implications for traditional social structures. The country is divided into districts, subdistricts, sukus (villages) and aldeias (hamlets)—aldeias being the more traditional of the two latter entities. According to Traube, the Portuguese imposed the territorial-based administrative system of sukus over a genealogically based system, so that many Timorese do not recognise sukus, or at least only relate to them as a purely geographic distinction. ${ }^{23}$ Each aldeia and suku is headed by a chefe or chief, and a suku council composed of the chefe aldeias and the chefe suku, together with five other members. While these roles are now elected, in many cases the positions are filled by traditional leaders who therefore bear both modern administrative and traditional authority.

19 Mac Ginty and Richmond, 'The Fallacy of Constructing Hybrid Political Orders', 225.

20 Ibid., 233.

21 McWilliam et al., 'Lulik Encounters and Cultural Frictions in East Timor', 314.

22 Boege, 'Potential and Limits of Traditional Approaches in Peacebuilding', 437.

23 Traube, 'Unpaid Wages', 20. 
Descent groups are geographically centred on the physical structure of a sacred house, or uma lulik, a term that is also synonymous with descent group and ancestral landholdings. The kinship system, as embodied by descent group, is the cornerstone of the Timorese social order. Traditional leaders at the head of such families are still the main source of mediation and local justice. They also act as a conduit between the government and their communities, facilitating government programs and projects at a suku level. This role is also enshrined in law and the constitution. ${ }^{24}$ It is a reasonable assumption, then, to believe that if you engage with a traditional leader, you are also engaging with the wider community delineated by suku or aldeia boundaries.

Even in rural areas, such assumptions are problematic. The legacy of displacement and forced resettlement under the Indonesian occupation has led to an often tense co-existence between original inhabitants and family groups resettled on their land. In many cases this has led to conflict. As described by Fitzpatrick et al. in their case study of land disputes in Ainaro Municipality in the central mountains of the country, for example, there are about six significant former 'transit' or 'concentration' centres for displaced persons from Ainaro and surrounding areas. ${ }^{25}$ These are also regular conflict flashpoints as the original occupants reassert their claim to the land and attempt to force the settlers back to their original landholdings, in a pattern common to a number of conflicts around the country.

The issue of demographic fragmentation is particularly pronounced in urban contexts. Dili has experienced exponential growth since independence. Forced resettlement and displacement under the Indonesian occupation and post-independence in-migration from rural districts has boosted Dili's population to more than eight times its 1974 pre-Indonesian invasion size of less than $30,000 .{ }^{26}$ While there have been a number of waves of migration, following different phases of the armed resistance against the Indonesian occupation, most of the growth has been since independence. According to the 2010 census, from 1999, Dili's population grew from 100,715 to around 252,884 and as much as half of this growth is due to migration from rural areas. ${ }^{27}$

24 Everett, Law and Justice in Timor-Leste.

25 Fitzpatrick et al., Property and Social Resilience in Times of Conflict, 227.

26 Ranck, 'Recent Rural-Urban Migration to Dili, Portuguese Timor'.

27 RDTL, 2010 Population Census. 
Then there is circular migration, which considerably swells the population of Dili in regular annual cycles. There are five to six significant temporary population movements per year in East Timor. In addition to population movements out of Dili, in August and September students arrive in Dili from the districts to register for school and university. There are other seasonal movements too, such as people coming in to Dili to sell agricultural produce-which many do on a daily basis. ${ }^{28}$

Migration patterns into Dili follow global chain migration patterns, ${ }^{29}$ whereby one family establishes a base and then 'sponsors' others from the extended family and home aldeia, helping them find housing and even employment. This means that enclaves of the rural aldeia of origin and extended family are established alongside enclaves of other migrant groups, creating a patchwork of different descent groups. In rural areas, an aldeia is essentially a family unit, but this principle largely holds true for established urban aldeias (although there is considerable variation), with one larger family dominating but with a number of smaller enclaves of other descent groups from other sukus or districts. ${ }^{30}$

Those areas composed of former Indonesian housing are different again. These new neighbourhoods were created almost overnight, when rural migrants rushed to occupy vacant Indonesian civil service and military housing. They are essentially squatter communities, or informal settlements, although many residents have formal or semi-formal claims to ownership. The cosmopolitan nature of these aldeias gives them a very different dynamic to the clan-centric traditional aldeias of the rural hinterland, or the still somewhat heterogeneous but older, more established aldeias in Dili. ${ }^{31}$

These informal settlements also have a highly transitory nature. A 2010 World Bank study found that at least 36 per cent of the inhabitants of one such neighbourhood had been there five years or less, and about 18 per cent had been there two years or less. ${ }^{32}$ Such frequent population movements make this a highly fluid social environment. Social dynamics therefore vary from aldeia to aldeia.

28 Scambary, 'Conflict and Resilience', 1942.

29 Choldin, 'Kinship Networks in the Migration Process', 164.

30 Scambary, 'Conflict and Resilience', 1938.

31 Ibid., 1940.

32 World Bank, Violence in the City. 
A recent World Bank report also described informal bairros or clusters of settlements within each aldeia, or within a suku. ${ }^{33}$ One of these, for example, was centred on the chefe suku's residence, comprising almost half of all the settlements in that aldeia, while others were situated along the main road. Some areas were more spread out or even uninhabited; some were well served by roads and public transport, while others were more isolated or even completely cut off. The report also described a number of different communities within different aldeias within this suku, including political, clandestine and religious groupings. ${ }^{34}$ Each of these groupings will have leaders who constitute alternatives to formal authority and structures such as chefe sukus or suku councils.

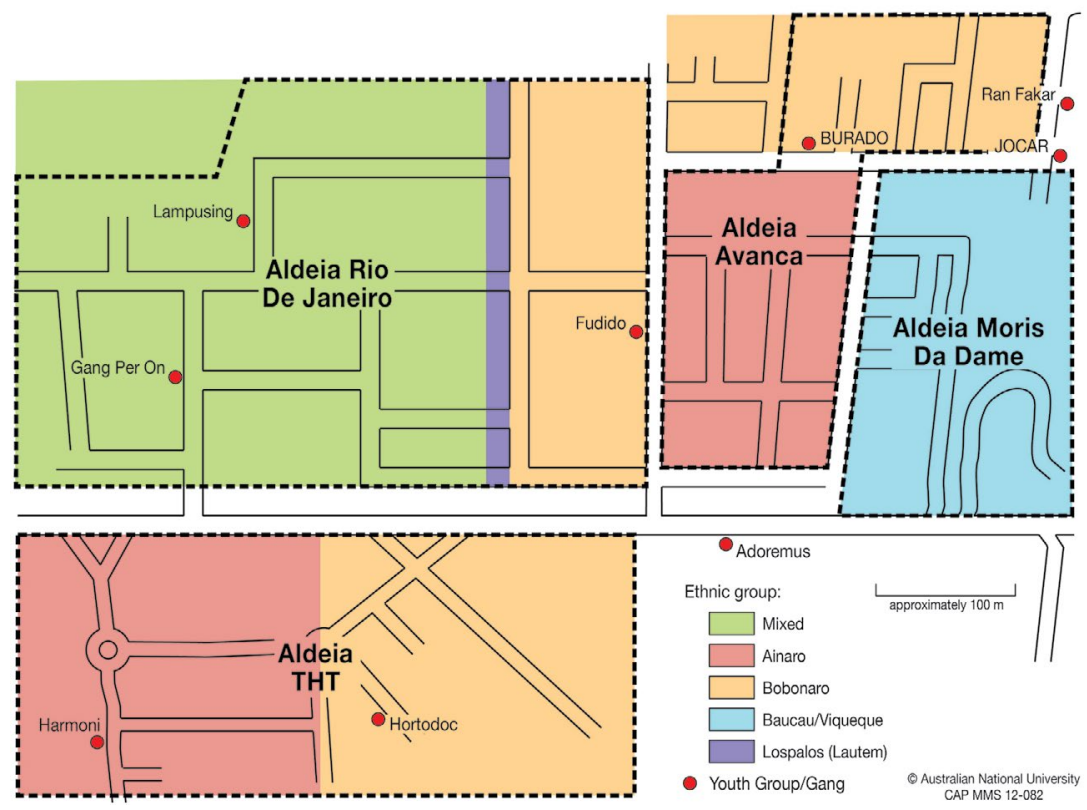

Figure 11.1: Linguistic group distribution per aldeia in Perumnas informal settlement, Dili

Source: The Australian National University, College of Asia \& the Pacific.

Apart from varying population density and a diversity of ethnolinguistic and descent groups (Figure 11.1), there are also contrasting class and occupational differences. Some suburbs are predominantly composed of civil servants, while others may be dominated by highly transient market

33 Muizarajs et al., Programa Nasional Dezenvolvimentu Suku Research and Evaluation Program.

34 Ibid. 
traders or shopkeepers - who in some cases are predominantly foreigners, such as Indonesians and mainland Chinese. Each of these constitute communities in themselves.

\section{Questions of legitimacy, localism and contested hybridity}

These factors have significant implications for hybrid approaches as well as more conventional approaches to peacebuilding. As a 2010 World Bank survey found, while traditional authorities were the main sources of security, there were often highly ambivalent attitudes towards them among their residents, varying considerably with each village. ${ }^{35}$ There are a number of reasons for this.

One reason is that during the communal violence of 2006-2007, village chiefs alienated sections of their communities in many cases through sectarian behaviour such as involvement in or endorsement of arson, looting and intimidation (there are numerous cases around Dili and nationally of traditional leaders also being martial arts group or gang leaders). Conversely, traditional leaders have sometimes gained respect across kinship and linguistic boundaries, either through neutrality, protecting victims or through playing a mediation role.

Another reason, however, is that as settlement patterns in hybrid urban neighbourhoods are highly fragmented, these can also be reflected in the dynamics of traditional leadership. Given that traditional authority stems from family lineage, the ad hoc, patchwork nature of these neighbourhoods makes it highly unlikely that any of the village chiefs represent their whole village in the way that they might in a conventional, rural village. Even when a leader comes from the same district and speaks the same language as their community, this does not guarantee authority. While in many more established aldeias, residents have accepted the authority of leaders from other descent groups over time, in the newer aldeias, it is unlikely that a chefe aldeia will have authority over any group other than their own descent group. In some aldeias, where one descent group predominates, for example, the chefe aldeia will have more authority, but some chefe de aldeias may only represent an enclave of their aldeia — a cluster of a dozen 
houses in one case. As stated earlier, cyclical and permanent rural-urban migration can also change the demographic status over time, so that one group may decline in numbers while another grows, which may lead to the undermining of chefe de aldeia authority.

In some instances, particular linguistic groups may be more scattered than others and may have no formal or traditional leadership at all. In the Dili suku of Bairro Pite, an area particularly hard hit by violence in 2006-2007, one resident from the Lospalos subdistrict in the eastern part of East Timor reported that despite being violently evicted from their houses in 2006 by many of their neighbours, because her community is scattered in pockets over four aldeias, they had never been involved in any peace process, as they do not have a formal leader. To further underscore the pitfalls of crudely employing hybrid approaches to peacebuilding, the same resident claimed that initially her community was represented at an INGO-sponsored peace process by the same chefe de aldeia who had looted her house during the 2006 violence. ${ }^{36}$

In such a heterogeneous environment then, the use of 'traditional' rituals like tara bandu is also highly problematic. The Lospalos resident cited above, for example, claimed that while she and her community voted for a widely respected chefe de aldeia from the western part of the country and allowed him to represent them in civil matters, this chefe de aldeia could not represent them in the case of a tara bandu ceremony, given that this ceremony draws on ancestral sanctions to enforce obedience. Only traditional leaders at the head of descent groups can conduct these ceremonies and they are only applicable to people from these descent groups.

In addition, as well as extended family groups, there are more than 35 language groups in East Timor. While these language groups may share many traits in common with other groups, as Hohe points out, there are a variety of complex traditional dispute resolution and justice mechanisms in East Timor, varying with each linguistic group and with the nature of the dispute or crime. ${ }^{37}$ As such, tara bandu is not common to all linguistic groups. According to McWilliam et al., the postindependence appropriation of the concept of tara bandu has effectively

36 Interview with Lospalos-born resident of Bairro Pite, Melbourne, 16 March 2010.

37 Hohe, 'The Clash of Paradigms'. 
hijacked a diverse range of traditions and reformed them into a different and more homogenous regulatory practice, in which the state is centrally involved. As they contend:

With this newly confected tara bandu, international development organisations as well as the government could press their conservationism and 'rule of law' upon the rural people. National NGOs, beholden to donors, followed suit. All development stakeholders participated in the idea that tara bandu was the essence of Timorese law..$^{38}$

The constant process of rural-urban migration, as described earlier, poses significant problems for ceremonies based on assumptions of static, settled communities. People from outside who enter the area regulated by a tara bandu are not bound by its sanctions. Indeed, communities interviewed for a 2011 report on an urban peacebuilding project complained about newcomers from the districts entering their aldeias and fracturing painstakingly negotiated reconciliation processes. ${ }^{39}$

Such heterogeneity and the fluid nature of conflict also means that the source of conflict or tensions can be misidentified, such as through attempts to mediate long-extinct 2006 east versus west tensions instead of a more recent 2007 murder, or mediation efforts directed at the wrong communities. ${ }^{40}$ As Boege notes, in segmentary societies, the legitimacy of the recourse to violence and the capacity to use it is vested in every segmentary unit of the society, which means that the potential for violence is widely dispersed. ${ }^{41}$ As described earlier, symmetries or interlinkages between descent groups, martial arts groups and political-party allegiance mean that tensions between any of these entities can become mutually generative. In a sense, these can be described as hybrid conflicts-they can be generated by many different causes at the same time, and take multiple forms. Many disputes in 2006 glossed as martial arts violence, or as electoral/political violence in 2007 , had a purely local aspect to them. Sometimes it was about pre-marital pregnancies, fights over perceived slights at wedding parties, disputes over a girl or, in one case, an extortion attempt on a bus driver. ${ }^{42}$ Sometimes the dispute was related to a conflict originating in a rural village. Given overlapping patterns of circular rural-

38 McWilliam et al., 'Lulik Encounters and Cultural Frictions'.

39 Catholic Relief Services, 'Laletek Program Final Evaluation'.

40 Interview with resident of Moris Ba Dame village, Bairro Pite, 16 March 2010.

41 Boege, 'Potential and Limits of Traditional Approaches in Peacebuilding', 438.

42 Interviews with UN Political Affairs, Dili, 24 July 2006; Belun conflict resolution team member, Dili, 24 October 2006; INGO conflict monitoring team member, Dili, 21 January 2008. 
urban migration, martial arts group, gang, family and political affiliations, these personal disputes erupted into much wider conflagrations that transcended static notions of localism.

This, in turn, has implications for scale—an important factor to consider in conflict resolution and peacebuilding. Nearly all the conflict of 2007, and since then, has been at the aldeia level, and yet most peace processes in the aftermath of the 2007 violence were aimed at the suku level. In one 2009 peace process, for example, the putatively opposing suku leaders gathered together were actually close friends or relatives. ${ }^{43}$ The conflict was between sections of each community, not the entire suku. As mentioned previously, the violence was sometimes perpetrated by community leaders against sections of their own community. Also, conflict maps completed for a 2010-2011 Catholic Relief Services urban conflict resolution project found that conflict tended to recur at particular crossroads or junctures, indicating the highly localised scale of most conflict and providing important clues as to who the antagonist groups were. ${ }^{44}$

Equally importantly, given that communal tensions may manifest in different forms at different times and places, thereby masking the original root of the conflict, the history of these conflicts needs to be more thoroughly investigated. Therefore, even if all the antagonist groups shared the same rituals and all appropriate traditional leaders were present to sanction the ceremony, it might still be a futile exercise if the underlying dynamics are ignored.

\section{Recent developments}

Such complexities are, however, beginning to be acknowledged in donor and INGO discourse. It is now increasingly recognised that more care must be taken in the use of rituals such as tara bandu, and that incorrect application of the procedures, such as not having the appropriate traditional authorities present, can seriously undermine the legitimacy of the process. As a report by Belun and the Asia Foundation noted, for tara $b a n d u$ to be successful in an urban context, it was vital to know the map

43 Interview with Bairro Pite mediation ceremony participant, Dili, 16 March 2010.

44 Catholic Relief Services, 'Laletek Program Final Evaluation'. 
of Dili', including knowing which communities are based in which areas and the nature of their historical and present-day interactions. ${ }^{45}$ The same could be said for rural areas too.

With the realisation that conflict is more complex and entrenched than previously thought, and equally as problematic in rural as urban areas, two parallel government departments were set up with donor assistance. One of these is the Department of Peacebuilding and Social Cohesion, within the Ministry of Social Solidarity, and the other is the Department of Community Conflict Prevention, located within the Ministry of the Interior (formerly the Secretariat of State for Security). With representatives placed at a district level, the main remit of these two agencies is the strengthening of conflict resolution capacity and mechanisms at the community level. While there are many problems with these bodies - which face challenges similar to all government departments such as resourcing and coordination with Dili-based managementnonetheless, their creation is an important recognition that communal conflict requires a longer-term, community-based approach.

Between 2010 and 2011, Catholic Relief Services ran a two-year peacebuilding project in 22 conflict-prone aldeias in Dili. ${ }^{46}$ At the very beginning of the project were two key departures from past practice. The first was that they did their homework on each community. They conducted an in-depth three-month baseline survey to identify not just the key fault lines in each community, but also the power dynamics among local leaders that prevented effective resolution. A common practice in donor and government programs is to work through chefe de aldeias and chefe de sukus. Apart from reinforcing patriarchal power structures, these predominantly male leaders frequently contact or include only their own family members in projects, effectively disenfranchising large sectors of the community. Recognising that these leaders were often the problem rather than the solution, Catholic Relief Services also used alternative actors such as local youth groups and even gang leaders to engage and mobilise their communities. The second departure was that participation was voluntary. Only communities requesting assistance would participate, and they had to demonstrate a willingness to resolve conflict themselves. Moreover, nobody was paid to attend meetings, as had been the previous

45 Belun and The Asia Foundation, Tara Bandu, 24.

46 Co-author James Scambary conducted the mid-term and final evaluations of this project. 
pattern by donors and also government departments - the notorious per diem payments that are now widely regarded as an entitlement for participation in any project.

Implementation of the project also differed from previous approaches in a number of other important ways. Recognising that conflict was hybrid and multi-level, the project itself rolled out multiple and sequenced activities to target these different levels and gradually shift people's attitudes towards reconciliation. Rather than treat gang leaders or members as 'spoilers', as they are so often referred to, it recognised that they are often just the vectors of community tensions and included them in the process, even giving them leadership roles. ${ }^{47}$ The project was run in partnership with the Catholic Church Dili Diocese Justice and Peace Commission, which lent further legitimacy to the project in a country where Catholicism is practised in tandem with traditional animist belief systems. In the case of one particularly intractable dispute, nuns accompanied Catholic Relief Services project workers in visits to the homes of the key antagonists, breaking the deadlock as a result. Five years later, approximately 18 out of the 22 communities continue to be largely free from conflict. ${ }^{48}$

After the divisions of 2006, substantial attention and funding has also been directed at policing, particularly in the area of formal institutional reform. While some gains have been made, there has been a gradual realisation that with ongoing management and resourcing problems, as per many government public services, and with the remote and difficult terrain of many rural areas, the police will always struggle to fulfil their mandate without the cooperation of the community. The Asia Foundation ${ }^{49}$ has been running a community policing project focused on the intersection between state security and community practices as a means to increase community safety and security. The main aspects of the program focused on setting up 123 community policing councils (CPCs) in 11 of 13 municipalities between 2012 and 2016. The CPCs bring together elected community members drawn from local and traditional authorities and ofisial polisia suku, or village police officers, in regular meetings to discuss and resolve suku security issues. The community members are typically from former clandestine resistance structures such as women's, veterans' and youth groups. Of equal importance, the CPCs aim to help community

47 Catholic Relief Services, 'Laletek Program Final Evaluation'.

48 Based on analysis of press reports and a field visit in 2015.

49 Co-author Todd Wassel was director, Security and Safety Program, and now deputy country representative, of the Asia Foundation, East Timor. 
members know and trust police officers, in a historical context where the state has been largely absent from community life and where the formal police have often been associated with domination, and therefore regarded with suspicion.

With enthusiastic support at senior levels of the PNTL command, indications so far are that the program has been a qualified success. Compared with 2008, data show there has been a significant change in justice-seeking behaviours by the population during the period CPCs have started. The 2015 Asia Foundation survey found that three out of four victims of crimes ended up at the police for assistance in 2015. The key difference in the recent survey is that the police are present in the majority of all successful resolutions at the community level, providing a wide variety of functions. These include ensuring security and adding legitimacy, to directly participating in the mediations and negotiations. The police are now just one stop along the justice-seeking path, with 76 per cent of all victims ending up at the community for conflict resolution. ${ }^{50}$

A local non-government organisation, Belun, with international support, has also been running a quietly effective peacebuilding project. The Conflict Prevention and Referral Network, through a districtbased network of trained volunteers, compiles information on violent incidents — which are published in Belun's 'Early Warning, Early Response' monthly reports - and conducts mediation. Network members are drawn from traditional and local authorities, women's groups, veterans and members of the PNTL.

Some of these creations emanate from the PNTL itself. One of these is a hybrid form of auxiliary policing known as security volunteers, which are part of a government-led initiative to embed police within communities. The security-volunteer initiative, driven by two district PNTL commanders, has been trialled in two particularly conflict-prone regions in East Timor-Viqueque and Liquisa. The security volunteers are intended to link the PNTL to remote rural areas, enhancing PNTL responsiveness to conflict, crime and accidents, and also to enhance local-level ownership of community security. These security volunteers are tasked with monitoring local-level crime and violence, which includes both communal conflict and gender-based violence. Their actual terms of reference are somewhat improvised and are an uncomfortable fit with more conventional ideas 
of human rights and policing-security volunteers have been known to physically 'arrest' people, tie them up and wait for the police or in other cases take them to the police station themselves. ${ }^{51}$ Nonetheless, while there is a range of other contributing factors, according to interviews with local peacebuilding actors, ${ }^{52}$ and judging by the considerable reduction of violent incidents in these two regions in press reports, these pilot programs have almost certainly contributed to a reduction in the intensity and frequency of violent incidents in Viqueque and Liquisa, as well as increased engagement by the police with communities. ${ }^{53}$

Some initiatives are driven by particular communities, and this is an increasing occurrence. In the district of Ermera in 2012, a districtwide tara bandu was held which set out regulations governing a wide set of public behaviours. This was in response to widespread community concern over the cost of lavish ceremonies including weddings and funerals and a variety of rituals, and a recognition that such occasions were also a common source of violence. Consequently, parents sometimes had difficulty with school expenses and even experienced food shortages. The local police commander has also trialled the use of traditional elders, known as kablehan, in a peacebuilding and community policing role. Kablehan traditionally mediate tara bandu ceremonies related to environmental conservation, and enforce sanctions. This role appears to be evolving, however, to include community mediation or conflict resolution, and even to resolve paternity suits and theft cases. ${ }^{54}$

A number of other highly localised community initiatives have also sprung up. One of these, for example, also based in Ermera District, is composed of about 21 members of the millenarian group Colimau 2000. Colimau 2000 was a key actor in the 2006-2007 violence, and although little understood, it is widely feared. With some training from the Catholic Church-run Justice and Peace Commission in Dili, this group has conducted conflict resolution sessions between local informal security groups, including Colimau 2000 and local martial arts groups. They also claim to play a preventive role by countering rumours that lead to conflict. ${ }^{55}$

51 Asia Foundation, The Proliferation of Security Providers.

52 As part of research for the report by the Asia Foundation, The Proliferation of Security Providers.

53 Both commanders have since been transferred, so it remains to be seen if the new commanders will continue to drive these programs. Belo and Rajalingam, Local Leadership of Community Policing Practices; Wassel and Rajalingam, A Survey of Community-Police Perceptions; Asia Foundation, The Proliferation of Security Providers.

54 Asia Foundation, The Proliferation of Security Providers.

55 Ibid. 


\section{Conclusion}

As Mac Ginty and Richmond contend:

hybridity is a condition that occurs, in large part, contextually; it is a constant process of negotiation as multiple sources of power in a society compete, coalesce, seep into each other and engage in mimicry, domination or accommodation.

It is from contextual and mediated, local, state and international legitimacy that a localized process of 'peace formation' arises. This means bottom-up rather than merely top-down empowerment [of] local and marginal actors, communities and individuals. ${ }^{56}$

These more recent donor-driven and locally initiated programs are not new in incorporating hybrid approaches. But as described above, many earlier efforts foundered on idealised notions of the value of traditional forms of leadership, locality, social organisation and structure. As we have seen, traditional community leaders have been politicised and mobilised in the name of sectarian violence in many areas. In localities suffering from endemic conflict over the past decade or so, these leaders and community structures clearly have been unable, or unwilling, to play an effective mediation role.

More recent initiatives have, however, sought to reinvigorate these community networks and, for the moment at least, have resulted in peace returning for a prolonged period to areas that had previously suffered from chronic conflict. Part of the reason for their success is improved local ownership, but also testifies to the more nuanced approach adopted to working with hybridity that acknowledges that times have changed. This approach recognises that there are a variety of other actors such as former clandestine networks, youth groups and even the church that are equally integral to engaging communities - that there is more than one type of hybridity. This does not mean that everything is perfect-there have been a number of violent confrontations between the police and communities in the past two to three years, and communal conflict continues to occur - but, overall, these developments provide hope for the future. 
This text is taken from Hybridity on the Ground in Peacebuilding and Development: Critical Conversations, edited by Joanne Wallis, Lia Kent, Miranda Forsyth, Sinclair Dinnen and Srinjoy Bose, published 2018 by ANU Press, The Australian National University, Canberra, Australia.

doi.org/10.22459/HGPD.03.2018.11 